\title{
Low-Temperature Cross-Coupling of Functionalized Grignard Reagents
}<smiles>CCOC(=O)c1cccc(I)c1</smiles><smiles>Cc1cc(C)c(C(C)(C)Cl)c(C)c1</smiles>

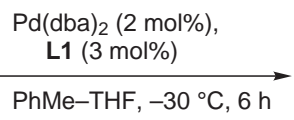<smiles>CCOC(=O)c1cccc(-c2c(C)cc(C)cc2C)c1</smiles><smiles>Fc1ccc(I)c(F)c1</smiles><smiles>CN(C)c1cccc(OC(F)(F)F)c1</smiles><smiles>Nc1cccc(-c2ccc(F)cc2F)c1</smiles>
$85 \%$

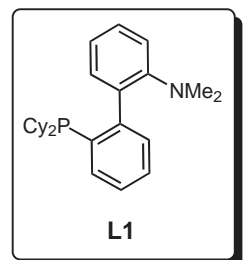<smiles>FC(F)(F)c1ccc(I)cc1</smiles><smiles>Clc1cc(Cl)nc(Cl)c1</smiles>

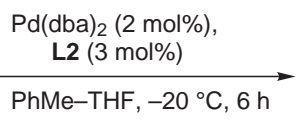<smiles>FC(F)(F)c1ccc(-c2cc(Cl)nc(Cl)c2)cc1</smiles>
$55 \%$

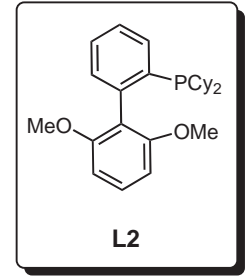<smiles>CCOC(=O)c1ccc(I)cc1</smiles><smiles>Fc1cccc(F)c1Cl</smiles>

$\mathrm{Pd}(\mathrm{dba})_{2}(2 \mathrm{~mol} \%)$ L2 (3 mol\%)

PhMe-THF, $-20^{\circ} \mathrm{C}, 6 \mathrm{~h}$<smiles>CCOC(=O)c1ccc(-c2c(F)cccc2F)cc1</smiles>
coupling of polyfunctionalized arylmagnesium species at the temperatures, which tolerate a vast majority of functional groups. This method is therefore extremely attractive for the direct synthesis of functionalized biaryls starting from (het)aryl halides.
Comment: While the preparation of polyfunctionalized (het)aryl Grignard reagents has become recently a great progress, the low temperatures (around $-40{ }^{\circ} \mathrm{C}$ in some cases) required for their stability limited their direct use in cross-coupling processes. The use of the new generation of biaryl phosphine catalysts, developed in the group of Buchwald, overcomes this problem. Several reactions can be performed even at $-65^{\circ} \mathrm{C}$, which has never been found for a Pd-catalyzed cross-coupling reaction.

Review: For a recent review on the preparation of polyfunctionalized Grignard reagents, see: $\mathrm{H}$. Ila, O. Baron, A. J. Wagner, P. Knochel Chem. Commun. 2006, 583-593. 